OPEN ACCESS

Vol. 5 No. 1 April 2017

Hal. 25 - 34
JAFFA

Journal of Auditing, Finance, and Forensic Accounting

E-ISSN: 2461-0607 ISSN: 2339-2886

http://jaffa.trunojoyo.ac.id/jaffa

\title{
RELATIONSHIP BETWEEN CONVERGENT-DIVERGENT THINKING CHARACTERS AND MIND MAP
}

Junaidi

Accounting Department, Faculty of Economics and Business, University of Trunojoyo Madura

\section{Article Info:}

Received: 10 Janaury 2017

in revised form: 10 February 2017

Accepted: 15 April 2017

Available Online: 12 November 2017

\section{Keywords:}

Mind Map, Accounting, Divergent, Convergent

\section{Corresponding Author:}

Email: azwar.junaidi52@gmail.com

\begin{abstract}
This study aims to evaluate the mind mapping material in creativity course syllabus. The test is performed to see the students' convergent-divergent thinking characters. The treatment of the accounting mind map using numerical symbols was given to students before and after the thinking character tests. The test used paired sample t-test, Wilcoxon, and Chi-Square. The test result proves that there is an increase of students' divergent thinking character after given the material of accounting mind map using numerical symbols compared to before treatment. However, there is no difference of convergent thinking characters in class $C$ before and after treatment.
\end{abstract}

\begin{abstract}
Abstrak; Penelitian ini bertujuan untuk melakukan evaluasi materi mind map pada silabus matakuliah kreativitas. Pengujian dilakukan untuk melihat karakter berpikir konvergen-divergen mahasiswa. Perlakuan mind map akuntansi menggunakan simbol angka diberikan pada mahasiswa sebelum dan sesudah pengujian karakter berpikir. Pengujian menggunakan paired sample t-test, Wilcoxon, dan Chi-Square. Hasil pengujian membuktikan bahwa terdapat peningkatan karakter berpikir divergen mahasiswa sesudah diberikan materi mind map akuntansi menggunakan simbol angka dibanding sebelum perlakuan. Namun pada kelas C tidak ada beda sebelum dan sesudah perlakuan atas karakter berpikir konvergen.
\end{abstract}

\section{INTRODUCTION}

The accounting stigma is difficult; it is relatively close to reality. Especially with the stipulation of IFRS version of accounting standards which requires the principle-based utilization. Educators are required to be more creative to change the reality so that business realm can obtain competent accounting graduates. However, it takes a lot of resources to change a mind, especially resource of ideas.

It cannot be denied that accounting textbooks can be one of the stigma resources. Those books restrict students' thinking characters to be more focused (convergent). The chapters that become material and learning objectives are split up into parts that are relatively incomplete i.e. based on account. Students have a higher probability of comprehending one type of account and journal well, but it would be better if students gain a comprehension by understanding both sides of a transaction that has the consequences of two or more accounts and journals.

By learning from both sides, it means that students are not undertaking a focused study (convergent), but a disperse study (divergent). This type of learning can also be a correction of the failed comprehension resource about accounting. It means that the students do not have the corrections of answers to the questions in individual tasks, 
whether it is true or false if they only learn based on one type of account (one journal). Students only seek truth through apriori, which is using their senses from the answers in the text, but they are lacking in terms of experience. Learning with mind maps provides an opportunity for students to learn as if they are experiencing accounting.

The effectiveness of learning with mind maps so that students can achieve an inherent comprehension of accounting has been investigated using deductive approaches like Ausubel (1963) and Novak (in Shimerda, 2007). Ausubel emphasize the importance of educator's role in understanding how learners comprehend the material of knowledge, but the more important thing is to understand how to summarize, connect and organize the material of knowledge in their minds. Shimerda (2007) inspectsthe Ausubel's theory developed by Novak. This researchuses accounting students as an object of research by providing treatment in the form of mind map.

$\mathrm{Ku}$ and Hang (2014) conduct a quasi-experiment towards accounting students through variance analysis tests (analysis of variance). The results of the research conclude that there are significant differences between the results of pretest and posttest of students studying accounting with mind maps. The results of this research confirm the results of previous research (Ku, Shih, and Hung, 2013). The results of the above research are also supported by the results of research that utilize mind maps using Nursing students as the object of research (D'Antoni, Zipp, Olson, and Cahill, 2010), English (Nosratinia and Kounani, 2016), and so forth, such as those examined by (Tartwijk, Vink and Verlop, 2015), (Liu and Wang, 2010), (Jang, 2010), and (Beydharani, 2015).

In general, people would prefer to see an image instead of a text. But according to Ausubel's theory, symbols can be used in the arrangement of images in mind maps. The use of symbols ascertains that humans think by encoding a text that has been decoded by the mind map maker. This thinking process makes accounting comprehension more inherent. However, it is not generally accepted. This type of learning is only effective for students who havea dispersed thinking character (divergent), and not necessarily effective for those with a focused thinking character (convergent). Unfortunately, the type of question that is generally asked in exams is the convergent question. Educator's understanding in arranging questions about accounting with a divergent type is still very minimal.

The number of research that split up students based on their thinking character is relatively small. Huang, $\mathrm{Li}$, Yeh, and Chang (2010) investigated student's divergent thinking character in solving problems. Theresults of the research conclude that brainstorming positively affect students in solving problems. Brainstorming also uses the principles of mind map based on Ausubel's theory. Study of Nuryana, Sulistyadi, and Murtini (2013) investigates the benefits of concept map using structural equation models. Results of the research conclude that there is a strong effect on the achievement of learning basic financial accounting II and the utilization of mind map concept. Gressgard (2012) separates observations on both types of student's thinking character, convergent and divergent. The tests conclude that the effectiveness of problem-solving skills can be found in students with divergent thinking character but not in students with convergent thinking character. Ghofrani (2012) found the opposite of the previous results.

The results of Ghofrani's research (2012) conclude that there is no relationship between leadership style and personality obstacles in the group of introvert employees. On the contrary, there is a negative relationship between leadership style and personality obstacles in the group of extrovert employees. This result indirectly confirms that humans are divergent; they have a better probability of solving a problem. (Nosratinia and Kounani, 2016) examine extroverted and introverted students with divergent and convergent types of tasks. The results conclude that both introverted and extroverted students are significantly capable of performing divergent tasks rather than convergent tasks.

In 2006, the curriculum of the Faculty of Economics of Trunojoyo University Madura implements the mentality, creativity, and critical sociology courses (MKS). This course is intended to give a balance between intellectual development and spiritual and emotional development. The tight accounting curriculum due to changes in accounting standards resulted in the probability of critical sociology course being removed. 
Setiawan, as the Head of Accounting Department, stated that "an evaluation of faculty's curriculum is needed to meet the demand of the curriculum changes and the implementation of Indonesia Qualification Framework (KKNI)." However, Triyuwono as the Dean of Faculty of Economics of Trunojoyo University 10 years ago stated that "MKS internalization is needed in accounting curriculum as an antithesis of the limitation of profit information." Gregoriades, Pampaka, and Michail (2009) emphasized the importance of curriculum changes through the management information system module evaluation by adding a mind map. Results of the study concluded that the method including mind map improved the quality of the learners.

Basically, humans think through the efforts of linking one word to another. Human's realm of thought seeks to find a new word by connecting it to the old word that has been embedded in the subconscious. Ausubel's theory calls this effort to connect as the creative thinking effort. Through the invention of a technology that provides a lot of mind map applications, there is a diversification of learning methods. The main weakness of learning using textbooks is the impact of linear writing which, to some extent, results in eyestrain and surfeited mind. Novak tests Ausubel's theory through an effective learning of connecting words and creates a creative thinking.

Novak and Gowin's research (1984) in Stice and Alvarez (1987) mentions that there are twenty steps in arranging a mind map. This research is intended to embed the children's comprehension of a word connected with other words, which can be done through labeling in the arrangement of three levels of accounting comprehension, namely accounting classification, principles of debits and credits, and journalism. If students pass the accounting classification stage, they can create the next sub-core, which are the principles of debits and credits. However, students are required to explore information and discuss if they fail.

After exploring information and discussing, students can try to compile the accounting classification then taking the test. If a group of students passes this stage, they may proceed to the next stage, the principles of debits and credits of each account. In this stage, students are required to explore information and discuss then present their mind map. Then they are asked questions to answer the second stage mind map. If the students fail, they can explore information and discuss to retake the second stage mind map. They can take the third mind map test, journalizing, after passing the second test. Beydarani (2007) calls this mind map system as the dynamic assignment system.

Budoff in Beydarani (2007) proposes a potential learning assessment model through test-derivation-test to assess learner's mental ability. Furthermore, Feurstein (in Beydarani, 2015) develops it by presenting a potential learning assessment tools through pretest-mediation-post-test. Later on, the development of Feurstein's assessment model becomes a pretest-learning-transfer-post-test. Ding (in Beydarani, 2015) arranged a standardized assignment that mediates the pretest and the post-test. The standardized assignment is used because it can be developed easily for various material subjects; it is then referred to as the dynamic assignment model. $\mathrm{Xu}$ (in Beydarani, 2015) observes a continuous standardized and non-standardized assignment can anticipate problems in learning that ultimately improve the learning ability of the learners.

Furthermore, Ku, Shih, and Hung (2014) offer a mind map model in three groups: first, describes accounting classifications; second, describes the principles of debits and credits; and third, journalizing. The results of this study conclude that student's understanding through mind map learning improves student's understanding as evidenced by post-test results.

Budoff in Beydarani (2015) propose a potential learning assessment model through test-derivation-test to assess learner's mental ability. Furthermore, Feurstein in Beydarani (2015) develops it by presenting a potential learning assessment tools through pretest-mediation-post-test. Later on, the development of Feurstein's assessment model becomes a pretest-learning-transfer-post-test. Ding in Beydarani (2015) arranged a standardized assignment that mediates the pretest and the post-test. The standardized assignment is used because it can be developed easily for various material subjects; it is then referred to as the dynamic assignment model. $\mathrm{Xu}$ (in Beydarani, 2015) observes a continuous standardized and non-standardized 
assignment can anticipate problems in learning that ultimately improve the learning ability of the learners.

Furthermore, $\mathrm{Ku}$, Shih, and Hung (2014) offer a mind map model in three groups: describes accounting classifications, principles of debits and credits, and third, journalizing. The researcher proposed mind map of early stage accounting as follows:

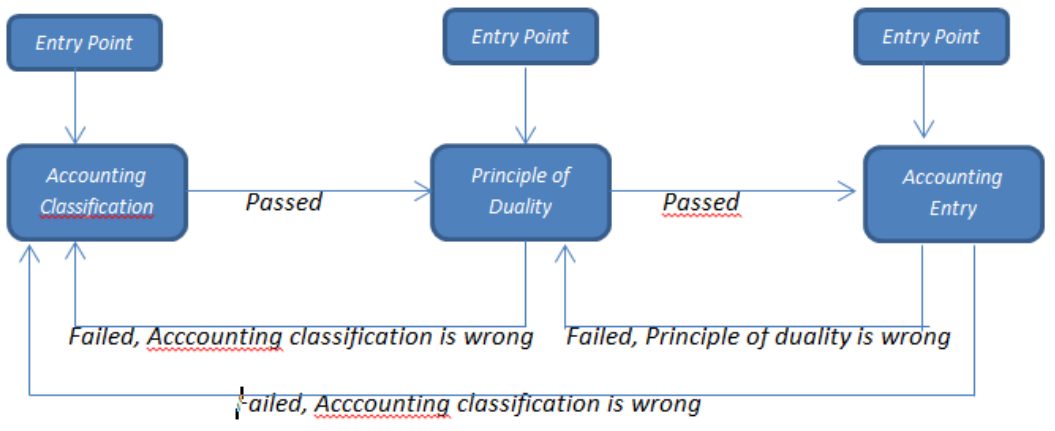

Figure 1: Accounting Mind Map

First, the researcher tests the students' ability to group accounts based on the group. Then, the researcher gives an understanding of principles of debits and credits. Afterwards, students are trained to arrange a journal. After that, mind map observation is focused on the complex journalizing principles. At this stage, the students have to dig up some information mainly on the principles of debit and credit on special transactions, such as convertible bonds.

Starting from the success of the above learning theories and the development of the world of technology with a variety of mind map applications based on the concept of thoughts mapping and word connectivity. Aleinikov (2002) proposed an alternative new learning relevant to the thinking characters, mind map. Students are expected to have divergent thinking to capture all possible probabilities of available information, and then explore information options that are then focused on a single problem-solving option.

Research that focuses on the concept of mind map at least includes three applications, as follows:

1. As a model of instruction: an educator can incorporate the concept of a map in learning as an assessment related to a given science material

2. As a tool for teaching and learning strategies: the concept of mind map reconstructs and embeds memories, then learners can search and explore derivative information on science material in a big frame.

3. As a tool of assessment and identification of the learners' lack of understanding: the effectiveness of learning can be known with a mind map and if learners do not understand then they can relearn it through mind map.

Application: WhatsUp and Mind Map through Gadgets. Nowadays, social media provides a lot of advantages to the society besides its shortcomings. The development of social media also supports the development of mind map application. There are several examples of free complex application, such as mindly, simplemind map, and schematicmind. Each application offers features that make it easier for users to have an inherent memory of the mind map frame. Basically, some of the common features are the central topic, connection, subtopic, sub-subtopic, and so on. Yang, Hwang, Hung, and Tseng, 2013) examined the utilization of gadgets as a media of mind map delivery to complement the e-book. Based on the above research, the following is the framework of embedding an accounting comprehension with the utilization of gadgets:

1. Make groups of 3 students

2. Make a WhatsUpgroup, at least one of each group and/or individual.

3. Upload mind map material (made by the educator) for 7 meetings and accounting $e^{-}$ books in WhatsUp group at the first lecture meeting.

4. Install bluestack and mind map apps on laptops at least one of each group and/or individual (for those who do not have laptops can utilize the Faculty of Economics of Trunojoyo University Madura computer labs that have bluestack and mind map installed) 
5. Each group must understand the mind map material then confirms it in the accounting e-book to be able to change the code (if necessary) delivered by the educator

6. Present the mind map material through symbol encoding at each lecture meeting, a course credit (SKS) by educator and one more course credit by student group

This research observes the students of Accounting Department of Faculty of Economics of Trunojoyo University Madura who take the creativity course. This faculty course requires students to think divergently. The test is done by questions to separate students on the selection of divergent and convergent thinking characters. The treatment is provided in accordance with the development of the creativity course syllabus, i.e. imaginary material using mind map and reasoning. The research questions asked is whether there are differences of divergent thinking characters before and after the implementation of mind map material. Pretest and post-test use paired sample ttest, Wilcoxon Rank Test, and Chi-Square.

\section{RESEARCH METHODS}

This research was a classroom action research. This research was performed to test whether the students' thinking process can be improved through learning using mind maps and reasoning. If there was a significant difference between pretest and post-test results, then it can be concluded that effective learning gives students a comprehension to choose divergent then convergent thinking to comprehend accounting.

First, the researcher conducted a pretest in the beginning of mid-semester (post mid-term) in the creativity course. Then, comprehension was taught through mind map examples and mind map assignments during 7 meetings of treatment-treatment. At the end of the semester, a post-test on the accounting comprehension was conducted. Accounting question tools used in the tests were account classification, principles of debits and credits, and journalizing.

\section{Analysis and Discussions}

Instrumental reliability test is conducted by using a split-half technique with alpha reliability coefficient assessment and Pearson Product Moment correlation. However, this research does not do the validity and reliability tests because the previous research has performed it.

In general, normality tests need to be performed to answer whether there are differences before and after treatment on the data of ratio scales questionnaire. The result of one sample Kolmogorov-Smirnov for class $\mathrm{A}$ and $\mathrm{C}$ both divergent and convergent thinking characters proves that the data is normally distributed. This study tests the results of divergent and convergent thinking characters before and after taking creativity course conducted in 2 groups of class, A and C. The tests are conducted to all of the creativity course students. The results of paired sample t-test for class A and C are shown in table 1.

Table 1: Results of Research using the Data of Questionnaire Score

\begin{tabular}{lllll}
\hline Class & Thinking & $\begin{array}{l}\text { T-Test } \\
\text { (Sig.) }\end{array}$ & $\begin{array}{l}\text { HO } \\
\text { rejected/accepted }\end{array}$ & Meaning \\
\hline A & Divergent & -1.88 & Rejected (on alpha & There are differences \\
& & $(0.06)$ & $10 \%)$ & before and after \\
& Convergent & -2.47 & Rejected & $\begin{array}{l}\text { There are differences } \\
\text { before and after }\end{array}$ \\
& & $(0.02)$ & & There are differences \\
C & Divergent & -2.14 & Rejected & before and after \\
& & $(0.03)$ & & There is no difference \\
& Convergent & 1.05 & Accepted & before and after \\
\hline
\end{tabular}

Based on table 1 , this study proves that the mind map treatment does not always work for groups of students who have divergent and convergent characters. In class A, 
mind map treatment is acceptable because there is a difference in the score of divergent thinking character before and after lectures even with alpha $10 \%$. Similarly, there is a difference in the score of convergent thinking character in class A before and after the mind map lecture. In class $\mathrm{C}$, the mind map treatment is well received because there is a difference in the score of divergent thinking character before and after the lecture. However, the result in the score of convergent thinking character in class $\mathrm{C}$ is different; there is no difference before and after the mind map lecture.

The results of this study did not succeed in supporting Gressgard's research (2012), but succeeded in supporting Feurstein's research (in Beydarani, 2015). For some students, the learning method that has long been ingrained which understands the material based on reading, listening, and case solving ability will be effective, but the learning character through decoding and encoding methods using mind map becomes less effective. However, for some students who always try new things and 'think out of the box', learning through mind map will be effective.

Furthermore, the test is done by scoring the divergent and convergent thinking characters through the $z$-score. Thinking characters of the subjects are categorized based on these following criteria:

1. $z_{\text {Div }} \geq 0,75$ and $z_{\text {Con }}<0$ Divergent

2. $z_{\text {Con }} \geq 0,75$ and $z_{\text {Div }}<0$ Convergent

Based on the results of $z$-score tests, there are 4 (four) thinking characters in students of Accounting Study Program of Faculty of Economics of Trunojoyo University Madura.Those are as follows.

Table 2: Convergent and Divergent Thinking Characters Score

\begin{tabular}{ll}
\hline Score & Thinking Characters \\
\hline 1 & Na \\
2 & Convergent \\
3 & Divergent \\
4 & Divergent-Convergent \\
\hline
\end{tabular}

Here are the results of tests conducted by scoring divergent and convergent thinking characters in students of Accounting Department of Faculty of Economics of UTM. The test is using the nonparametric Wilcoxon Sign Rank Test because the data has an ordinal scale. The test is performed in class $\mathrm{A}$ and $\mathrm{C}$ to prove the character before and after the treatment in the form of mind map lecture. Observation and reduction of outlier data were performed prior to the test. There are 9 outliers of 79 data; therefore, it is reduced to 70 data only. The results are shown in table 3.

Table 3: Results of Students' Thinking Characters Test Score

\begin{tabular}{lccl}
\hline \multicolumn{1}{c}{ Class } & Z-Test (Sig.) & $\begin{array}{c}\text { HO } \\
\text { rejected/accepted }\end{array}$ & \multicolumn{1}{c}{ Meaning } \\
\hline $\begin{array}{l}\text { Before- } \\
\text { after }\end{array}$ & $-2.87(0.004)$ & Rejected & $\begin{array}{l}\text { There are differences in } \\
\text { thinking characters before } \\
\text { and after treatment }\end{array}$ \\
\hline
\end{tabular}

Based on test results in divergent and convergent thinking scales, the test results before and after applying learning with mind mapsis proven to be effective in class A and C. The total score of the 70 students before treatment was 119 , but after the treatment, there is an increase to 147 . These results support research by (Vink, Tartwijk, and Verlop, 2015), (Liu and Wang, 2010), (Jang, 2010), and (Beydharani, 2015).

The next test is separated, if the previous tests are applied to all students, then the Chi-Square test is separated between the successful and unsuccessful students. The success-failure indicator does not have any consequences for the students' ability to comprehend accounting. The test with success-failure separation is performed to see whether or not there are students who can increase or even decrease their thinking characters because of the mind map material. The following are the results of students class A and C tests. The results are shown in Appendix 1.

The test is conducted by using Chi-Square and categorized into success and failure as well as the sum. The following is the test's results presented in table 4 . 
Table 4: Non-Parametric Chi-Square Test Results

\begin{tabular}{lccl}
\hline \multicolumn{1}{c}{ Class } & $\begin{array}{c}\text { Chi-Square } \\
\text { (Sig.) }\end{array}$ & $\begin{array}{c}\text { Ho } \\
\text { rejected/accepted }\end{array}$ & \multicolumn{1}{c}{ Meaning } \\
\hline Success-Failure & $8.582(0.00)$ & Rejected & $\begin{array}{l}\text { there are differences } \\
\text { before and after } \\
\text { Total }\end{array}$ \\
& $4.08(0.04)$ & Rejected & $\begin{array}{l}\text { there are differences } \\
\text { before and after }\end{array}$ \\
\hline
\end{tabular}

The results of this test successfully proved the hypotheses that mind map effectively improves students' thinking characters. There is a significant difference between students who successfully improve their divergent-convergent learning character and the failed ones in both class A and C. These results support (Vink, Tartwijk, and Verlop, 2015), (Liu and Wang, 2010), (Jang, 2010), and (Beydharani, 2015).

\section{SUMMARY AND SUGGESTIONS}

Discussions related to students' thinking characters require discussion from a psychological point of view, but this study only observes from a limited point of view on the functions of connecting, organizing and remembering of students using mind maps. The conclusion that can be given as input for institutions is that the mind mapping material is still relevant to the syllabus, learning programs and semester study plan for the creativity course. The limitations of this study are as follows:

1. Validity and reliability tests resulted in a lot of data reduction. Hence, the validity and reliability tests are performed in this study.

2. The discussion about mind mapping material review on accounting only refers to one research findings.

3. Research respondents are students who were taught by the educator who performs the research. Thus, the subjectivity of research cannot be avoided.

\section{REFERENCES}

Aleinikov, G, Andrei 2002, Mega Kreativitas. Penerbit Niagara

Anthony V. D'Antoni, Genevieve Pinto Zipp, Valerie G. Olson and Terrence F. Cahill. 2010. Does The Mind Map Learning Strategy Facilitate Information Retrieval and Critical Thinking in Medical Students? BMC Medical Education., 61-72.

Ausubel, D. 1963. The Psychology of Meaningful Verbal Learning. New York: Grune \& Stratton.

Beydarani, Vahideh. 2015. The influence of concept mapping on reading comprehension of Iranian English students employing persuasive and descriptive texts. Journal of Language Teaching and Research., 196-221.

Biniecki, Susan M. Yelich and Conceicao, Simone C.O.. May 2016. Using Concept Maps to Engage Adult Learners in Critical Analysis. Adult Learning, 51-71.

Ghofrani, Mohsen. 2012. Relationship Between Leadership Styles and Personality Traits Of Physical Education Managers of Education in Khorasan Razavi. Advances in Environmental Biology, 1797-2008.

Gregoriades, Andreas, Pampaka, Maria and Michail, Harris. 2009. Assessing Students' Learning in MIS Using Concept Mapping. Journal of Information Systems Education, 419-426.

Gressgard, Leif Jarle. 2012. Text-Based Collaborative Work and Innovation: Effects of Communication Media Affordances on Divergent and Convergent Thinking in GroupBased Problem-Solving. Interdisciplinary Journal of Information, Knowledge and Management. 
Huang, Chun-Chieh, Yeh, Ting-Kuang, Li, Tsai-Yen and Chang, Chun-Yen. 2010. The Idea Storming Cube: Evaluating The Effects of Using Game and Computer Agent to Support Divergent Thinking. Educational Technology \& Society, 180-201.

Jang, S-J. 2010. The Impact on Incorporating Collaborative Concept Mapping With Coteaching Techniques in Elementary Science Classes. School Science and Mathematics., 86-102.

Leauby, B.A. and Brazina, P. 1998. Concept Mapping: Potential Uses in Accounting Education. Journal of Accounting Education, 123-138.

Liu, M-C and Wang, J-Y. 2010. Investigating Knowledge Integration in Web-Based Thematic Learning Using Concept Mapping Assessment. Educational Technology \& Society. 25-37.

Kao, Gloria Yi-Ming, Chen, Kuan-Chieh and Sun, Chuen-Tsai. 2010. Using an ELearning System With Integrated Concept maps to Improve Conceptual Understanding International Journal of Instructional Media, 151-171.

Ku, David Tawei, Shih, Ju-ling and Hung, Su-Huan. 2014. The Integration of Concept Mapping in A Dynamic Assessment Model For Teaching and Learning Accounting. Educational Technology \& Society, 141-154.

Nosratinia, Mania and Kounani, Kolsum. 2016. Comparing The Impact of Divergent and Convergent Tasks on Extrovert and Introvert EFL Learners' Writing Performance. Theory and Practice in Language Studies, 1305-1315.

Novak, J. D. 1999. How do we learn Our Lesson?: Taking Students Through The Process. The Science Teacher, 60 (3), 50-55.

Novak, J.D. 1998. Learning, Creating, and Using Knowledge: Concept Maps as Facilitative Tools in Schools and Corporations, Mahwah, NJ: Lawrence Erlbaum

Nuryana, Ita, Sulistyadi, Kohar and Murtini, Wiedi. 2013. Pengaruh Strategi Pembelajaran Concept Map Terhadap Prestasi Belajar Dasar Akuntansi Keuangan II Berdasarkan Tipologi Belajar. Jurnal Pendidikan Insan Mandiri. Vol.2 No.1. 42-52.

Raval, Vasant and Shimerda, Thomas A. 2002. Integrating AIS Course Content Using Concept Maps. The Review of Business Information Systems, 85-95.

Shimerda, Thomas A,. 2007. Concept Mapping: A Technique to Aid Meaningful Learning in Business and Accounting Education. Indian Journal of Economics and Business, 117-132.

Vink, Sylvia C., Bolk, J and Verloop, N. 2015. Integration of Clinical and Basic Sciences in Concept Maps: A Mixed-Method Study on Teacher Learning. BMC Medical Education., 20-32.

Yang, Che-Ching, Hwang, Gwo-Jen, Hung, Chun-Ming and Tseng, ShianShyong, 2013). An Evaluation Of The Learning Effectiveness of Concept Map-Based Science Book Reading Via Mobile Devices. Educational Technology \& Society, 167-188. 
Appendix 1 Data Clustering Based on Binomial

\begin{tabular}{|c|c|c|c|c|c|c|c|}
\hline \multicolumn{4}{|r|}{ CLASS C } & \multicolumn{4}{|l|}{ CLASS A } \\
\hline Before & After & Difference & Up/Down & Before & After & Difference & Up/Down \\
\hline 1 & 3 & 2 & success & 2 & 1 & -1 & failed \\
\hline 1 & 1 & 0 & & 1 & 2 & 1 & success \\
\hline 2 & 3 & 1 & success & 2 & 1 & -1 & failed \\
\hline 2 & 1 & -1 & failed & 3 & 2 & -1 & failed \\
\hline 3 & 2 & -1 & failed & 1 & 2 & 1 & success \\
\hline 2 & 1 & -1 & failed & 3 & 2 & -1 & failed \\
\hline 2 & 4 & 2 & success & 1 & 1 & 0 & \\
\hline 1 & 3 & 2 & success & 1 & 1 & 0 & \\
\hline 2 & 2 & 0 & & 1 & 1 & 0 & \\
\hline 2 & 2 & 0 & & 2 & 1 & -1 & failed \\
\hline 1 & 3 & 2 & success & 2 & 4 & 2 & success \\
\hline 2 & 1 & -1 & failed & 2 & 1 & -1 & failed \\
\hline 2 & 3 & 1 & success & 2 & 2 & 0 & \\
\hline 1 & 1 & 0 & & 2 & 2 & 0 & \\
\hline 1 & 2 & 1 & success & 1 & 1 & 0 & \\
\hline 1 & 1 & 0 & & 4 & 1 & -3 & failed \\
\hline 2 & 2 & 0 & & 1 & 4 & 3 & \\
\hline 4 & 4 & 0 & & 4 & 2 & -2 & failed \\
\hline 1 & 3 & 2 & success & 1 & 3 & 2 & success \\
\hline 2 & 4 & 2 & success & 1 & 2 & 1 & success \\
\hline 2 & 4 & 2 & success & 1 & 1 & 0 & \\
\hline 2 & 4 & 2 & success & 4 & 4 & 0 & \\
\hline 4 & 2 & -2 & failed & 1 & 1 & 0 & \\
\hline 3 & 3 & 0 & & 2 & 4 & 2 & success \\
\hline 2 & 1 & -1 & failed & 1 & 4 & 3 & success \\
\hline 2 & 2 & 0 & & 1 & 4 & 3 & success \\
\hline 4 & 3 & -1 & failed & 2 & 2 & 0 & \\
\hline 2 & 1 & -1 & failed & 1 & 1 & 0 & \\
\hline 1 & 1 & 0 & & 2 & 4 & 2 & success \\
\hline 1 & 1 & 0 & & 1 & 1 & 0 & \\
\hline 3 & 1 & -2 & failed & 1 & 1 & 0 & \\
\hline 1 & 1 & 0 & & 1 & 1 & 0 & \\
\hline 3 & 1 & -2 & failed & 3 & 2 & -1 & failed \\
\hline 2 & 2 & 0 & & 2 & 4 & 2 & success \\
\hline 4 & 2 & -2 & failed & 2 & 4 & 2 & success \\
\hline 2 & 3 & 1 & success & 2 & 1 & -1 & failed \\
\hline 3 & 3 & 0 & & 2 & 2 & 0 & \\
\hline 2 & 1 & -1 & failed & 1 & 4 & 3 & success \\
\hline 2 & 1 & -1 & failed & 2 & 4 & 2 & success \\
\hline 1 & 1 & 0 & & 1 & 2 & 1 & success \\
\hline
\end{tabular}


